\title{
Information And Communications Technology: A Comparative View Of Technological Determinism
}

James W. Gabberty, (E-mail: JGabberty@Pace.edu), Pace University Robert G. Vambery, Pace University

\begin{abstract}
Misinterpretations by techno-centric managers hold that advances in information and communications technologies (ICT) are the prime causal factors in future business growth and that technology is an independent variable from which operational performance can be predicted. Technology pundits and economic futurists are convinced that the 'new economy' has indeed become reality as competitive pressures dramatically rise as a result of the increasing interdependencies forming among competing nations and firms. This competition has been made possible, in part, by the commercially viable World Wide Web and its superstructure known as the Internet. This paper scrutinizes the invaluable role played by information and communications technologies and the technological determinism they propagate.
\end{abstract}

\section{INTRODUCTION}

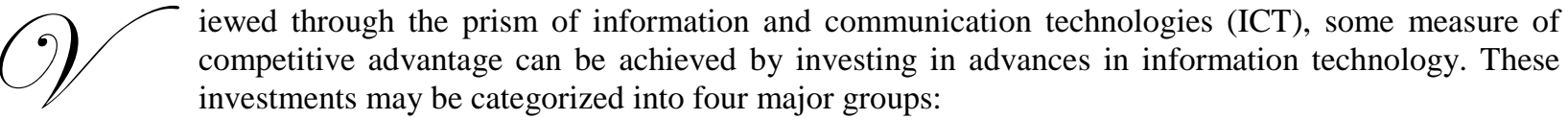

1. The acquisition of the newest ICT architectures and operating environments, such as broadband telecommunications equipment, distributed database and application servers, cellular 'smart' phones, 'thin' client applications, etc.;

2. Fluency and proven aptitude in the comprehensive suite of current and leading-edge ICT products and services;

3. An increasing reliance on existing ICT infrastructures (such as the Internet), complemented by government regulation and policies (such as copyright protection and information security) to maintain stable transnational linkages and assure uninterrupted transnational data flow (Gabberty, 2004);

4. A clear and demonstrable mindset among senior executives who view ICT as vital to the overall mission of their companies.

Today, efforts to interlink all operational aspects of the firm continue unabated as optimistic business leaders and technologists ramp-up the firm's infrastructures in anticipation of the arrival of the second wave of eCommerce. In this 'second coming' era, it is not yet clear whether the notion of technological determinism will earn permanent status as a component of corporate strategy; however, nearly all firms - small, medium and large - maintain a mindset that ICT is an important strategic lever and, if used appropriately, provides a means to achieve increased access to markets and ostensibly, to new sources of revenue.

This paper proposes the concept of technological determinism as one of the critical success factors in global marketing competitiveness. In brief, technological determinism may be described as causing: 
1. major social and historical changes at the macrosocial level of social structure and processes; and/or

2. subtle but profound social and psychological influences at the microsocial level of the regular use of particular kinds of tools (Chandler, 1996).

However, it is also useful in forming a context for approaching the understanding of relationships between technology and organizations in order to predict future changes in social systems (Marx and Smith, 1994). As such, it focuses on technology as an independent and deterministic factor of how organizations and, in the larger context, society will change as a result of progressive innovations in technology and the subsequent importation and incorporation of new technologies into the firm or social structures. Further, it can be argued that those corporations which are lead by forward-thinking senior executives that add technology to their marketing strategy are more likely to produce more successful outcomes than those who do not.

\section{ICT AS A SOURCE FOR COMPETITIVE ADVANTAGE}

The push for achieving competitiveness by pursuing a corporate strategy intensely dependent on ICT is a familiar theme, paralleling the view that technology acts as an external change agent both in society and in organizations (Attewell and Rule, 1984). In the 1960s and 1970s the adoption of mainframe computers was viewed principally as the result of (a) demonstrable evidence of dramatic savings achieved through automation of rudimentary tasks such as payroll processing, inventory control, and accounts payable \& receivable and (b) empowering middle management with the capability of sifting through vast quantities of information, pushing decision-making to lowers organizational levels. Each of these rationales brought about increased managerial control and a drastic reshaping of the organizational and social structures of the firm (Blauner, 1964; Leavitt and Whisler, 1958; Zimbalist, 1979).

Following this early adoption of ICT by mainly large corporations, the proliferation of the personal computer in [mostly] U.S. business during the 1980s brought about a similar change in organizational structure, but with different results (Gabberty, 1985). Whereas mainframe computers caused a move toward centralization of corporate structures, personal computers gave rise to a dispersed, flattened managerial structure, where work would be performed by dispensing smaller, more manageable units or tasks, all made possible by computer networking, which, in turn, gave rise to information sharing and the genesis of collaboration (Drucker, 1988; Gabberty, 2005).

Lured by promises of project investments that yielded returns several orders of magnitude higher than original investments, a rush of Internet startup firms characterized the late 1990s. By harnessing the networking capabilities of the Internet and tying back-office legacy databases to sophisticated client applications residing on customers' personal computers, the objective of affecting a seamless integration of the corporation's vast ICT architecture gave rise to the organizational phenomenon referred to as the 'virtual corporation' (Goldman and Nagel, 1995; Rayport and Sviokla, 1995; Preiss et al., 1996; Davenport, 2000).

Many of these so-called 'dot com' firms had only three or four years of operational history and may have had some notion as to where technology fit into their marketing mix but from a practical perspective, they lacked the requisite skills necessary to effectively incorporate these technologies into their operations. This had the disastrous effect of instigating the failure of more than 90 percent of these firms, many filing for bankruptcy protection immediately after the start of the new millennium. ${ }^{1}$ Some examples of the failed endeavors include Pets.com, Garden.com, eToys.com, eStamps.com, and Boo.com; hundreds of other dotcoms with an aggregate equity market loss in excess of $\$ 1.77$ trillion would later be seen as signaling the death knell of the Internet firm frenzy and, some would argue, of technological determinism. ${ }^{2}$ More of a theory than a scientific principle, technological determinism

\footnotetext{
${ }^{1}$ Actually, many other factors contributed to the failures of the dotcoms. Here are some cited by INC Magazine - (1) The "Lots of Money, But No Vision" Dilemma; (2) The "Business as Web Site" Approach; (3) The Money Burn Rate; (4) The Speed Trap a.k.a. "Getting to market first"; and (5) The Lemming Syndrome. Source: Walters, Jamie, "Why Dot-Coms Failed (And What You Can Learn from Them)", INC, September 2001.

${ }^{2}$ CNNfn.com asked the market data and research firm Birinyi Associates of Westport, Conn., to calculate the market value of the 280 stocks in the Bloomberg US Internet Index at their respective 52-week highs and their current market value. The combined market values of the 280 stocks had fallen to $\$ 1.193$ trillion currently from $\$ 2.948$ trillion at their peak, a loss of $\$ 1.755$ trillion,
} 
seeks to explain social phenomena (manifest both inside and outside the firm) in terms of one primary, deterministic factor. In the context of ICT, the technology implied by technological determinism refers to the ubiquitous personal computer, regarded by many as driving the 'microelectronic revolution' (Jones, 1990; Large, 1980).

However, the relative success of those few ICT-centric businesses that successfully leveraged the potential aggregate processing power and extensive reach of the Internet would keep alive the notion that technological advances, when used as an operational aid in corporations, does indeed suggest a permanency for technology in the strategic marketing mix. The promise of new business forms catalyzed by Internet-based technologies is one which envisions firms of any size marketing its goods and services to a global community. This gave rise to a plethora of smaller-sized firms competing in market spaces traditionally reserved for larger, more internationalized companies. For these smaller firms, ICT represents a watershed in their evolution. For large companies, it means access to even larger markets that lead to an increase in the number of competing firms within these markets (Schwartz, 1997; Rayport, 1999; Tang et al. 2003).

For firms of all types, new technologies represent the prospect of opening new markets but concomitantly requiring sizeable investments in computing and communications hardware as well as trained personnel in order to become operationally efficient (Davenport, 1997; Weill and Broadbent, 1998; Perkins and Perkins, 1999; Devaraj and Kohli, 2002). Further, the complexity of new technologies and shortsightedness of many senior executives who lack a clear understanding of where technology should fit in their firms' overall strategy can limit and often thwart the otherwise contiguous notion of technological determinism. This does not imply a weakness of the core tenets associated with technological determinism but instead suggests culpability on the part of senior managers who misinterpret how technical advancements adversely affect the firm if deployed improperly.

\section{TECHNOLOGICAL DETERMINISM REDUX?}

For firms like Amazon.com, customers browsing the online bookseller in the mid-1990s perceived a tightly coupled mesh of product information and up-to-date inventory database seemingly tied to real-time credit card processing capabilities, with interoperability extensions to overnight shipping firms. In reality however, the firm relied heavily on 'sneaker-net' technology that merely used the hard copies of printed customer orders to fulfill orders by hand in much the same way that booksellers fulfilled orders decades before. But from the customers' perception, the illusion was real enough to draw tens of thousands of visitors per day from all corners of the globe to browse Amazon's virtual bookshelves (Burgelman and Meza, 2001). Today, Amazon's state-of-the-art, highly-coupled supportive ICT infrastructure provides apparent seamless integration between internal and external databases of all kinds as well as sophisticated software capable of predicting customer interests in other products, based on the order profile of individual customers and of all others exhibiting similar product interests and purchasing patterns. While other online booksellers vie for a small piece of market share, Amazon uses its technological sophistication to promote continued expansion of the firm (Luftman et al., 1999; Gillenson et. Al, 1999; Sing, 2002).

Another successful and early adopter of the Internet is the Sony Corporation. By relying heavily on the World Wide Web to make available extensive product information to a global audience, it learned how to use the Internet as part of its corporate marketing strategy to the extent that its PlayStation line of gaming devices utilizes the Internet to allow gamers spread across the globe to share the gaming experience (Mak, 2003). Starting with the straightforward objective of reducing operational costs, the firm began replacing expensive glossy product brochures with their online equivalent in the mid-1990s, a practice now mimicked by leading consumer electronic firms. Other competitors in this market space, such as Olympus America, maker of numerous photographic equipment products and imaging services, uses ICT somewhat differently than Sony. It reduces information dissemination costs by including lengthy product user guides and reference manuals on digital CDs distributed with their products instead of traditional printed manuals or the newer method of online distribution. Though not nearly as effective as making this information available to consumers online, Olympus, Inc. nevertheless saves millions of dollars in printing costs each year (Cooper, 1994).

most of which occurred between March and September of this year. Source: Kleinbard, David, “The \$1.7 Trillion dot.com Lesson”, Money, November 9, 2000. 
Likewise, the U.S. government was early to recognize the inherent capabilities of the Internet and related technologies, first allowing millions and then tens of millions of U.S. tax payers to file annual tax returns online. Other U.S. government agencies have followed suit and extensively incorporated the Internet as part of their strategy to serve American taxpayers. For example, The Statistical Abstract of the United States - an economic report summarizing all the business activities and economic statistics of the United States - was available up through 1995 only in book form. Starting in 1996, the abstract also became available on CD-ROM and sold for approximately \$200; after 2001, the abstract was made available free of charge through the U.S. Department of Commerce web site as part of the realization of the government's declared strategy as outlined in the 2002 E-Government Strategy initiative. ${ }^{3}$ Moreover, as technology develops, newer and more effective ways to individualize constituent support are planned.

In sum, organizations like Amazon, Dell, EBay, Google, numerous banks (e.g. Chase.com and Citibank.com), retail chains (e.g. LLBean.com, WalMart.com, and BestBuy.com), the travel industry (e.g. JetBlue.com, Avis.com, Orbitz.com, and Expedia.com), and price search engines (e.g. PriceGrabber.com, NextTag.com) are led by senior management teams who not only recognize the greater efficiencies that can be gained by leveraging new ICT technologies, but they actually create entirely new ways of marketing services. These firms distinguish themselves by mixing aspects of marketing with their strategic operational approach and, in sum, bring about causal responses from consumers that may be deterministic responses. They recognize that by using ICT in a focused and deliberate fashion, they can create and leverage opportunities to provide accompanying marketing services while sustaining operational efficiency. Some of them even collect non-product related revenues by selling access to their online experience to third party marketing firms (through pop-up windows, for example) or by selling the information they glean from customers to competitor firms. In all instances, the strategic use of ICT not just as an operational lever but rather as a marketing tool has brought about somewhat predictable marketing successes and indirectly, lead to greater overall corporate growth, and for firms such as Amazon, EBay, and Google, vast increases in asset values (Wolfe, 1994; Hendriks, 2001; Senge, 2001; Meyronin, 2004).

\section{NEW FOUNDATIONS SUPPORTING TECHNOLOGICAL DETERMINISM}

In the mid- to late 1990s, the rise of computer networks, then the Internet, gave rise to the "frictionless economy", where exponential growth in outsourcing and the advent of the virtual organization would usher in new forms of work and corporate governance (Senn, 2000; Wareham et al. 2005). This resulted in almost completely flattening existing managerial structures and the introduction of a completely new class of managers who understood the potential opportunities and pitfalls accompanying these new technologies. In nearly each case, the availability and adoption of these new technologies and their aggregate impact on organizational structures was somewhat predictable as to how, where, and why organizations would be changed. For some firms, these changes were not readily understood while for others, the changes represented affirmation that the views held by insightful managers envisioning ICT in a new light were indeed correct.

Thus far in the early $21^{\text {st }}$ century, existing ICT technologies are employed more or less in the same manner by a majority of firms within competing industries. In some cases, banks for example, these deployments do not lead to significantly divergent results of rival firms (Olazabal, 2002). In other cases, such as airline ticketing agencies, the results may differ from firm to firm as daily operations are infused with technology (Jet Blue, for example). Here too, the operational processes are easily mimicked, yet predicting the outcomes from ICT outlays and implementation may not prove an easy task (Costa et al., 2002).

\footnotetext{
${ }^{3}$ The July 18, 2001 Memo (U.S. OMB Memorandum M-01-28) established an E-Government Task Force to identify priority actions that achieve strategic improvements in government and set in motion a transformation of government around citizen needs. According to this report, "More than 60 percent of all Internet users interact with government websites. E-Government will save taxpayers a significant amount of money, while adding value to citizens' experience with government and better serving their needs. Consequently, the President has made "Expanding E-Government" integral to a five-part Management Agenda for making government more focused on citizens and results. Federal information technology (IT) spending in the United States will exceed $\$ 48$ billion in 2002 and $\$ 52$ billion in 2003. That level of IT spending provides enormous opportunities for making the transformation government into a citizen-centered E-Government. Indeed, a good portion of current federal IT spending is devoted to Internet initiatives, yielding over 35 million web pages online at over 22,000 web sites." Source: E-Government Strategy: Simplified Delivery of Services to Citizens “, February 27, 2002.
} 
It can be argued that technological determinism of late, has, in many instances, failed to sustain the organizational changes that were successfully forecast and subsequently witnessed in earlier years when technology adoption spread throughout the enterprise and lead to more complex organizational structures (Zaheer, 1995; Pisanias and Willcocks 1999; Brooke, 2000; Dalglish and Newton, 2002; Rosenberg, 2005). This point is made more clear by examining similar-sized firms competing within the same industrial sector, each possessing nearly identical technologies (more or less implemented in much the same way), but yielding diametrically opposed or otherwise dissimilar results.

Often the subtle disparities between performance levels of competing firms can be traced to diverse managerial styles of ICT usage and dissimilar ICT governance practices such as employee training programs. Even so, and in still other circumstances, two competing organizations using similar methodological approaches to deploying ICT may, in fact, yield atypical outcomes (Hill, 1996; Chapman et al., 2000; Saravanamuthu, 2002; Quéau, 2002). There are myriad ways this phenomenon may be explained but most often, they usually differ because of the fundamental differences dominating the mentality that each firm maintains toward ICT as well as the perceived strategic direction these firms assume ICT will take them. For example, competitor firms Amazon.com, BarnesandNoble.com and BooksAMillion.com each have more or less the same user interfaces and overall processing capabilities, yet neither has a market share anywhere near that of the Amazon.com, the industry leader.

By revisiting the concept of technological determinism from the context of a predictive change agent, not necessarily from the purview of organizational structure, but rather from the perspective of global marketing competitiveness, the reasons why successful firms in certain industries perform better than others may become clearer. Whereas during the forty year period leading up to the dotcom crash, technological determinism may have been an instigating factor in organizational and social change, its utility as a sole predictive indicator in ICT campaigns certainly has become obviated, notably since firms possessing similar architectures simply do not exhibit similar outcomes. However, this does not necessarily mean that technological determinism is finished. It does, arguably, suggest that a newer, more updated approach to technological determinism is called for. From this modified perspective, the predictability aspect of technological determinism stays intact.

Accordingly, the inclusion of technology to the long list of deterministic variables in formulating marketing strategies can lead to greater successes in achieving sustainable competitive advantage, contingent, minimally, upon comprehensive and unambiguous guidance from top management. In all instances, technological agility as a requisite source of new product design and business methods, and of downstream marketing activities enhances international performance. (Knight and Cavusgil, 2004).

To be consistently effective, this suggests modification of the principle tenets of technological determinism requiring that its application in marketing campaigns needs to be a dynamic process in which successes are evaluated, related to changing environmental conditions, and formulaically added to new findings from market research, and then fed back into the process of developing what becomes the new marketing strategy. This systematic process is rigorous and requires a mindset shared by employees throughout the firm as information is collected, analyzed, and updated. (Gabberty and Thomas, 2005). While the feedback mechanism is a system of re-enforcement and the temptation to depend on it solely as a barometer of continued firm successes are great, too much reliance on it can lead to both internal and external imitation of previous competitive practices and thereby lead to a breakdown of the ability to predict potential outcomes.

Bonabeau (2004) identifies important motivations for limiting dynamic changes, including (1) the safety associated with consciously avoiding big mistakes, (2) the drive to conform and (3) the assumption that other competitors are likely to know better. If used consistently, the proposed cyclical process can not only propel the firm from market participant to a market maker; if unchecked, market gains may erode if techno-centric executives focus excessively on risk and cost savings rather than on innovation and creativity (Campbell, 2003). Understanding the markets in which firms operate can also enhance the capabilities of the firm such that the firm gets to "know customers so well that they can develop (marketing) solutions that provide great value to customers before the customers recognize that they actually require it" (Saint-Onge and Armstrong, 2004). 


\section{GLOBALIZATION AND THE ROLE PLAYED BY ICT}

The impact that ICT has on the global economy is partly governed by the technological sophistication of ICT improvements and their downstream effects as drivers of the business function as well as the degree to which technological determinism has caused organizations and societies to evolve. Table 1 lists some of these drivers.

Table 1: ICT Global Marketing Drivers

\begin{tabular}{|cl|}
\hline$\checkmark$ & Access to telephony and telephony-related services \\
$\checkmark \checkmark$ & Deregulation, policy and taxation concerns \\
\hline$\checkmark$ & Distributed databases and their interoperability \\
\hline$\checkmark$ & Downward trends of ICT prices \\
\hline$\checkmark$ & Higher capacity telecommunication conduits \\
\hline$\checkmark$ & Increased strategic management and outsourcing capabilities \\
\hline$\checkmark$ & Increases / decreases of piracy by developing nations \\
\hline$\checkmark$ & Internet availability and cost \\
\hline$\checkmark$ & New developmental and deployment methodologies \\
\hline$\checkmark$ & Overall hardware improvements \\
\hline$\checkmark$ & Rising rates of technological diffusion \\
\hline$\checkmark$ & Specialized application software \\
\hline$\checkmark$ & Supply chain management (SCM), enterprise resource planning \\
\hline$\checkmark$ & (ERP), and customer relationship management (CRM) software \\
\hline
\end{tabular}

As two substantial factors affecting business today, globalization and the Internet also significantly impact the international marketing function of global firms (Rayport \& Jawarski, 2001). The information gleaned from externalities enable firms to arbitrage operational flexibility as a consequence of their internationally dispersed network of affiliates (Rugman \& Verbeke, 2004). Further, as firms internationalize, the benefits associated with arbitraging global relationships provides them the capability to compete effectively in external markets, and therefore to have earned the moniker 'globalized'.

Before this occurs, however, a firm must identify, assess, plan, and respond to the availability and overall advancement of ICT infrastructures that it can leverage in terms of (1) existing domestic and international linkages, (2) local and international Internet service providers, (3) consumers' level of knowledge and skill sets, and (4) firmspecific ICT support systems as identified in Figure 1. 
Figure 1: ICT Forces Influencing Technological Determinism

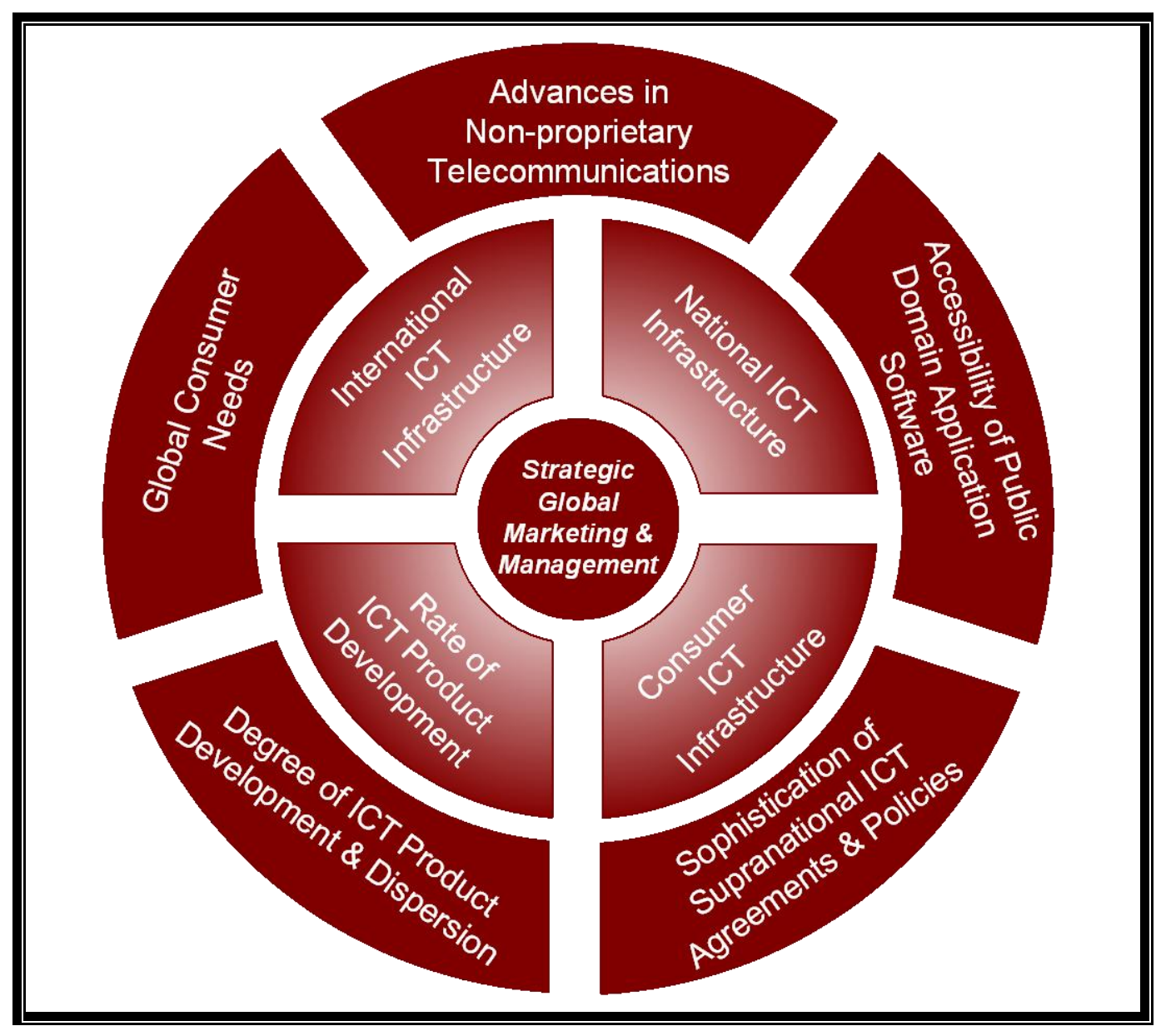

From a causal viewpoint, technology joins the inner core of the international marketing function. It faces such opposing forces as (1) global consumer needs, (2) the degree of ICT product development and dispersion, (3) sophistication of supranational ICT agreements \& policies, and (4) accessibility to public domain application software. To launch successful global marketing campaigns, firms must perpetually strive to attain a level of mastery in each of the component categories identified in the illustration.

Technological determinism has evolved to outgrow its roots as an independently occurring phenomenon affecting social and organizational structures. Besides encompassing all the components outlined in Figure 1, it is more akin to strategic choice, a concept which brings together managerial and organization strategies, ideologies and political dynamics as determinants that are technology motivated (Orlikowski \& Iacono, 2000).

Finally, technological determinism is influenced by organizational informatics, or the amalgam of commercial, governmental and international policy systems. As such, organizational informatics can also be considered a useful driver that impacts organizations using ICT and the rate at which organizations change their structures to compete internationally (Kling \& Lamb, 2000). 


\section{INTERNATIONAL IMPLICATIONS}

From an international perspective, expansion efforts can also be seen as centering on ICT to achieve heightened country-level competitiveness as demonstrated by developing nations such as India and China. Here, the leaders of those nations are in the midst of directing a large transformation of specific industries and national infrastructure that make use of the Internet and the latest advances in ICT. For example, the Indian Institute of Science is singled out in the Indian budget as a center of excellence in research and development to be promoted as a "worldclass university". Also, the bullish projections for Indian ICT and ICT-enabled services produced by McKinsey \& Co. forecast that the combined industries will, by 2008, employ 4 million people - up from fewer than 900,000 in $2004-$ and earn between $\$ 57$ billion and $\$ 65$ billion from exports - compared with $\$ 17$ billion in 2004 - and account for 7 percent of GDP - compared with 4 percent). ${ }^{4}$

In China, the ongoing state-sponsored "Golden Projects" agenda, begun in 1997, represents the future for a networked China to continue to pursue its efforts to join the ICT-enabled global society. Cumulative figures for total spending on these projects vary as data sources conflict, but it is estimated that they range between $\$ 1$ billion to nearly $\$ 3.5$ billion through the year 2000, then subsequently tapered off to a lowered maintenance figure in excess of $\$ 100$ million per year (Gabberty, 2004).

Together, these projects represent significant opportunities for foreign companies seeking to do business with India and China to leverage the Internet and associated technologies. The relative successes of these initiatives are reflected in China's envious buildup of its massive internal manufacturing capabilities and in India's now famous facilities for software outsourcing and call centers. By developing national ICT infrastructures in these countries, the leaders of these governments help to provide their respective constituents with the necessary ICT environment to assist continued economic expansion efforts among domestic firms contending for international business activity (Christmann and Taylor 2001; De la Torre and Moxone, 2001; Leamer and Storper 2001; Qu and Brocklehurst, 2003; Kotlarsky and Oshri' 2005).

The leaders of other nations also view ICT as a key determinant of their respective country's long-term economic health. The cooperation among sovereign governments to relax taxes on data flows in an effort to extend the seamless sharing of data across national boundaries is a critical feature of this forward-thinking scenario that is characterized by consumers making use of expanded access to suppliers and distributors selling products and services worldwide (Laffont and Tirole, 2000).

The trend of expanding growth by leveraging ICT to compete globally has resulted in myriad business opportunities. The advent of the World Wide Web has brought together so many electronic marketplaces that in the mid-1990s, the term marketspace was coined to encompass the electronic, informational, or technological arenas in which business activities occur, margins are created, and value is extracted using new market channels. Specifically, these information-defined transactions (or value creation and extraction in the marketspace) therefore create new ways of thinking about making money and thus a new value proposition (Rayport \& Sviolka, 1994). The continual process of relentless listening to consumer preference provides marketing strategists with "live" customer feedback which, prior to the passage of the 1996 Telecommunications Act, was simply unobtainable and may be one of the reasons why technological determinism fell short of expectations (Barabba and Zaltman, 1991; Quelch and Klein, 1996; Urban et al., 2000).

\section{CONCLUSION}

The relative importance of ICT investments made by Western firms competing for global market shares cannot be overestimated. Specific measures among companies competing in this marketspace should make use of and leverage the latest advances in information and communication technologies available, such as:

\footnotetext{
${ }^{4}$ Source: The Economist, “The Bangalore Paradox”, April 21, 2005.
} 
1. Data mining software that sifts through exponentially-growing quantities of transactions in relational databases reflecting consumer purchasing patterns;

2. Enterprise-wide software applications that link together the disparate and geographically distributed ICT assets of large multinationals whose complex technology architectures often fall short of providing business leaders with access to timely and accurate business data;

3. Advancements in point-of-sale software applications increasingly used by consumers making use of newer technologies such Smart Cards and Smart Phones;

4. Artificial intelligence software applications that sift through massive inflows of transactional data and provide predictive analysis in which trend identification and examination can be made, as commonly used to study global equity markets and foreign currency exchange rates.

By leveraging these technologies, firms can enhance their current competitiveness as well as create new sustainable competitive advantage. The era of globalization shows no signs of abating as nations such as China and India are quickly discovering and leveraging the latent values that belie advances in ICT. Western nations and their corporations must endeavor to maintain and even accelerate the continuous development of their technological leaderships.

\section{REFERENCES}

1. Attewell, P. and J. Rule (1984) Computing and Organizations: What We Know and What We Don't Know. Communications of the ACM 27(12): 1184-1191.

2. Barabba, Vincent and Gerald Zaltman (1991) Hearing the Voice of the Market: Competitive Advantage through Creative Use of Market Information, pp. 61-63. Harvard Business School Press. Cambridge.

3. Blauner, R. (1964) Alienation and Freedom, pp, 37-42. The University of Chicago Press. Chicago.

4. Bonabeau, Eric (2004) The Perils of the Imitation Age. Harvard Business Review 82:6 (June): 47.

5. Brooke, Carole (2000) A Framework for Evaluating Organizational Choice and Process Redesign Issues. Journal of Information Technology 15:1 (March): 17-28.

6. Burgelman, Robert A. and Meza, Philip (2001) Amazon.com: Evolution of the e-Tailer. Harvard Business Case Product Number SM83 (March): 2-4.

7. Campbell, A. J. (2003) Creating Customer Knowledge Competence: Managing Customer Relationship Management Programs Strategically. Industrial Marketing Management, 32:5 (July).

8. Chandler, Daniel (1996) Shaping and Being Shaped. Computer-Mediated Communication Magazine 3:2 (February): 1-1-0.

9. Chapman, Paul, Mike James-Moore et al. (2000) Building Internet Capabilities in SMEs. Logistics Information Management 13(6): 353-361.

10. Christmann, Petra and Glen Taylor (2001) Globalization and the Environment: Determinants of Firm SelfRegulation in China. Journal of International Business Studies 32:3 (September): 439-458.

11. Cooper, Robin (1994) Olympus Optical Co. Ltd. (A): Cost management for Short Life Cycle Products. Harvard Business Case Study Product Number 9-195-072 (August): 2-4.

12. Costa, Peter R., Harned, Doug S., and Jerrold T. Lundquist (2002) Rethinking the Aviation Industry. McKinsey Quarterly Special Edition: Risk and Resilience 2(2): 4-5.

13. Dalglish, Carol and Caroline Newton (2002) The Relationship between Firm Survival and Innovation: An Introduction to the Literature (Review) Innovation: Management, Policy \& Practice 4:1/3 (December 2001/June 2002/December 2002).

14. Davenport, Thomas H. (1997) Information Ecology, pp. 37-38. New York. Oxford University Press.

15. Davenport, Thomas H. (2000) Mission Critical, pp. 266-272. Cambridge. Harvard Business School Press.

16. De la Torre, Jose, and Richard W. Moxon (2001) Introduction to the Symposium E-Commerce and Global Business: The Impact of the Information and Communication Technology Revolution on the Conduct of International Business. Journal of International Business Studies 32:4 (December): 617-639.

17. Devaraj, Sarv and Rajiv Kohli (2002) The IT Payoff, pp. 73-74. Upper Saddle River, New Jersey. PrenticeHall.

18. Drucker, Peter F. (1988) The Coming of the New Organization. Harvard Business Review (JanuaryFebruary):3-5. 
19. Gabberty, James W. (1985) The Proliferation of the Personal Computer in American Business. Engineering Management Review 13:4 (December): 18-22.

20. Gabberty, James W. (2004) Revving the Innovation Engine in China, Japan, and the United States. Innovation: Management, Policy \& Practice 6:1 (April): 78-79.

21. Gabberty, James W. (2005) Reflections on the Coming of the New Organization. International Journal of Technology, Knowledge and Society (Accepted for publication July 2005).

22. Gabberty, James W. and Jennifer D. E. Thomas (2005) Toward a Model of Creativity for the Multinational Firm. Proceedings of the Pan Pacific Conference XXII held at Zhejiang University, Shanghai, China (May). The University of Nebraska. Lincoln, Nebraska.

23. Gillenson, Mark L., Sherrell, Daniel L., and Lei-da Chen (1999) Information Technology as the Enabler of One-to-One Marketing. Communications of the Association for Information Systems 2:18 (September).

24. Goldman, Steven L. and Roger N. Nagel (1995) Agile Competitors and Virtual Organizations pp. 84-97. John Wiley \& Sons. New York.

25. Hendriks, Paul H. J. (2001) Many Rivers to Cross: From ICT to Knowledge Management Systems. Journal of Information Technology 16:2 (June): 57-72.

26. Henman, Paul and Mitchell Dean (2001) E-Government: Transformations in Modes of Rule? Innovation: Management, Policy \& Practice 4:1 (December): 5-11.

27. Hill, Rosemary (1996) A Measure of the Learning Organization. Industrial and Commercial Training 28(1): 19-25.

28. Jones, Barry (1990) Sleepers, Wake! Technology and the Future of Work, p. 210. Oxford University Press. Melbourne.

29. Kling, R. and R. Lamb (2000) IT and Organizational Change in Digital Economies: A Socio-technical Approach. in Brynjolfsson, Erik and Brian Kahin, editors (2000) Understanding the Digital Economy: Data, Tools and Research, pp. 295 - 315. MIT Press. Cambridge.

30. Knight, Gary and Tamar Cavusgil, Innovation, Organizational Capabilities, and the Born-Global Firm. Journal of International Business Studies 35:2 (March): 132.

31. Kotlarsky, Julia and Ilan Oshri (2005) Social Ties, Knowledge Sharing and Successful Collaboration in Globally Distributed System Development Projects. European Journal of Information Systems 14:1 (March): 37-48.

32. Laffont, Jean-Jacques and Jean Tirole (2000) Competition in Telecommunications: Munich Lectures in Economics, pp. 217-231. MIT Press. Cambridge.

33. Large, Peter (1980) The Micro Revolution, pp. 13 - 21. Fontana. London.

34. Leamer, Edward E. and Michael Storper (2001) The Economic Geography of the Internet Age. Journal of International Business Studies 32:4 (December): 641-665.

35. Leavitt, H, and T. Whisler (1958) Management in the 1980s. Harvard Business Review 36: 41-48.

36. Luftman, Jerry N., Papp, Raymond, and Tom Brier (1999) Enablers and Inhibitors of Business-IT Alignment. Communications of the Association for Information Systems 1:11 (March).

37. Mak, K-T and A Ramaprasad (2003) Knowledge Supply Network. Journal of the Operational Research Society 54:2 (February): 175-183.

38. Marx, L. and Mr. R. Smith, editors (1994) Does Technology Drive History?, pp. 13-29. MIT Press, Cambridge.

39. Meyronin, Benoit (2004) ICT: The Creation of Value and Differentiation in Services. Managing Service Quality 14(2): 216-225.

40. Olazabal, Nedda (2002) Banking: The IT Paradox. McKinsey Quarterly 1(1): 45-51.

41. Orlikowski, Wanda (1992) The Duality of Technology: Rethinking the Concept of Technology in Organizations. Organization Science 3(3): 398-427.

42. Perkins, Anthony B. and Michael C. Perkins (1999) The Internet Bubble, pp. 107-110. HarperCollins. New York.

43. Pisanias, Nikolaos and Leslie Willcocks (1999) Understanding Slow Internet Adoption: 'Infomediation' in Ship-broking Markets. Journal of Information Technology 14:4 (December): 399-413.

44. Preiss, Kenneth, Steven L. Goldman and Roger N. Nagel (1996) Cooperate to Compete, 163-164. Van Nostrand Rheinhold. New York. 
45. Qu, Zhonghua and Michael Brocklehurst (2003) What Will it Take for China to Become a Competitive Force in Offshore Outsourcing? An Analysis of the Role of Transaction Costs in Supplier Selection. Journal of Information Technology 18 (March): 53-67.

46. Quéau, Philippe (2002) Global Governance and Knowledge Societies. Development 45:4 (December): 10-16.

47. Quelch, John A. (1999) Global Brands: Taking Stock. Business Strategy Review, 10 (Spring): 1-14.

48. Rayport, Jeffrey F. and John J. Sviokla (1994) Managing in the Marketspace. Harvard Business Review (November-December): 6-10.

49. Rayport, J. F., and John J. Sviokla (1995) Exploiting the Virtual Value Chain. Harvard Business Review, November: 75-85.

50. Rayport, Jeffrey F. (1999) The Truth About Internet Business Models. Strategy + Business, $3^{\text {rd }}$ Quarter.

51. Rayport, Jeffrey F. and Bernard J. Jaworski (2001) e-Commerce, pp. 26 - 30. McGraw-Hill. New York.

52. Rosenberg, Justin (2005) Globalization Theory: A Post Mortem. International Politics 42:1 (March): 2-74.

53. Rugman, Alan M. and Alain Verbeke (2004) A Perspective on Regional and Global Strategies of Multinational Enterprise. Journal of International Business Studies 35:1 (January): 16.

54. Saint-Onge, Hubert and Charles Armstrong (2004) The Conductive Organization: Building Beyond Sustainability, p. 28. Elsevier. Oxford.

55. Saravanamuthu, Kala (2002) Information Technology and Ideology. Journal of Information Technology 2:17 (June):79-87.

56. Schwartz, Evan I. (1997) Webonomics, pp. 174-183. Doubleday Broadway Books. New York.

57. Senge, P. M., G. Carstedt, et al. (2001). Innovating Our Way to the Next Industrial Revolution. MIT Sloan Management Review 42(2): 24-38.

58. Senn, J.A. (2000) Business-to-Business eCommerce, Information Systems Management 17(2): $23-32$.

59. Sing, Nitish and Sumit Kundu (2002) Explaining the Growth of E-Commerce Corporations (ECC): An Extension and Application of the Eclectic Paradigm. Journal of International Business Studies 33: 679-697.

60. Tang, Fang-Fang, Marcel G. Thom et al. (2003) Using Insurance to Create Trust on the Internet. Communications of the ACM 46:12 (December): 337-244.

61. Urban, Glen L., Sultan, Fareena and William J. Qualls (2000) Placing Trust at the Center of Your Internet Strategy. Sloan Management Review 42:1 (Fall): 39-48.

62. Wareham, Jonathan, Zheng, Jack G. and Detmar Straub (2005) Critical Themes in Electronic Commerce Research: A Meta-Analysis. Journal of Information Technology 20: 1-19.

63. Weill, Peter and Marianne Broadbent (1998) Leveraging the New Infrastructure, pp. 49-50. Harvard Business School Press. Cambridge.

64. Wolfe, R. A. (1994) Organizational Innovation: Review, Critique and Suggested Research Directions. Journal of Management Studies 31(3): 405-431.

65. Zaheer, Srilata (1995) Circadian Rhythms: The Effects of Global Market Integration in the Currency Trading Industry. Journal of International Business Studies 26:4 (December): 699-728.

66. Zimbalist, S., editor (1988) Case Studies on the Labor Process. Monthly Review Press. New York. 


\section{NOTES}

